Nunt. Antiquus, Belo Horizonte, v. 17, n. 1, p. 31-54, 2021

\title{
Escolas filosóficas em contraste e uma tópica platônica em Filóstrato, Vida de Apolônio de Tiana I, VII.
}

\section{Philosophical schools in contrast and a platonic commonplace in Philostratus, Life of Apollonius of Tyana I, VII.}

\author{
Rogério Gimenes de Campos \\ Universidade Federal da Integração Latino-Americana (UNILA), Foz do Iguaçu, \\ Paraná / Brasil \\ rogedecampos@gmail.com \\ https://orcid.org/0000-0002-5813-2730
}

Resumo: No trecho I, VII da Vida de Apolônio de Tiana, Filóstrato descreve sinteticamente a adolescência de Apolônio, sua breve estadia em Tarso até sua mudança para Egas, momento em que Apolônio terá um novo e excêntrico professor. Veremos no trecho por nós previamente analisado e traduzido: (i) como o do domínio do ático de Apolônio, expresso por Filóstrato, revela um exemplar anacronismo, (ii) como são expostos alguns traços estereotipados acerca das escolas filosóficas com as quais Apolônio teria tido contato e, finalmente, (iii) como a metáfora do crescer das asas provavelmente provém de uma tópica platônica, especificamente do Fedro (Phdr. 249c4-256b6).

Palavras-chave: aticismo, escolas filosóficas no Império Romano, Filóstrato, vida pitagórica, Apolônio de Tiana.

Abstract: In the passage I, VII of the Life of Apollonius of Tyana, Philostratus synthetically describes Apollonius' adolescence, his brief stay in Tarsus until his move to Egas, when Apollonius will have a new and eccentric teacher. We will see in the excerpt previously analyzed and translated by us: (i) how the Attic domain of Apollonius, expressed by Philostratus, reveals an exemplary anachronism, (ii) how some stereotyped traits are exposed about the philosophical schools with which Apollonius would have had contact and finally (iii) how the metaphor of growing wings probably comes from a Platonic commonplace, specifically from Phaedrus (Phdr. 249c4-256b6).

Keywords: Atticism, philosophical schools in the Roman Empire, Plato, Philostratus, Pythagorean life, Apollonius of Tyana. 


\section{Flávio Filóstrato \\ Vida de Apolonio de Tiana I, VII}

Tendo atingido a idade em que são ensinadas as letras, ele (Apolônio) demonstrou uma notável memória e forte empenho, e já teria dominado o dialeto ático, sem se afastar do sotaque de sua etnia, de modo que os olhos de todos se voltaram para ele, sendo admirado em toda parte. Com a idade de quatorze anos, seu pai o levou para Tarso, junto a Eutidêmo, o fenício. Eutidêmo era um bom rétor e o ensinou, mas embora ele agora tivesse um mestre, a cidade tinha um caráter extravagante (átopon) que não propiciava adequado ambiente para o estudo da filosofia. Em nenhum lugar havia maior sujeição ao luxo e à vida frívola, todos viviam em excessos e davam mais valor à vestimenta do que os atenienses à sabedoria. Um rio flui por essa cidade, o Kydnos, no qual muitos permaneciam sentados ${ }^{1}$, tais quais os pássaros aquáticos. Apolônio em uma carta endereçada a eles disse: "cessai dessa embriaguez na água". Mudou em seguida de professor por demanda do pai e foi para um local próximo, a cidade de Egas, na qual o sossego era propício para a atividade filosófica e os mais jovens ali nela se empenhavam, e [havia] ali um templo de Asclépio em que o próprio Asclépio se manifestava aos homens. Nela filosofavam conjuntamente platônicos, crisipianos (estoicos) e os do peripato (aristotélicos), enquanto ele ouvia também os discursos de Epicuro, pois não os renegava, embora tenha adotado o [a filosofia] dos pitagóricos com uma inefável sabedoria. O professor dele dos discursos pitagóricos não era muito aplicado, nem se valia dessa filosofia na sua própria vida, pois era derrotado pela glutonaria e pelos prazeres de Afrodite, sendo moldado pela filosofia de Epicuro. Era Euxêno de Heracleia, da região do Ponto, que conhecia as opiniões de Pitágoras tal qual os pássaros que aprendem junto aos homens a dizer: "Olá!" e "que estejas bem" e "Zeus te ajude" e todas essas coisas que se demanda aos pássaros, sem que se conheça o que dizem, nem que seja favorável aos homens, mas apenas uma língua treinada. Então [Apolônio] estava como as jovens águias com asas ainda delicadas e que voam próximo dos seus genitores, que são instrutores em seu voo. Depois disso se tornam capazes de subir, sobrevoam seus pais e outros lugares, e quando percebem comida e odor são levadas ao voo em direção a terra, assim Apolônio teria se dedicado a Euxêno desde jovem e foi conduzido por ele no seu ingresso na arte do discurso, mas tendo chegado à idade de dezesseis anos foi tomado pelo desejo de vida dos pitagóricos, pois uma força fez com que suas asas crescessem (pterôtheìs ep' autòn hupo tinos kreittonos). Ele não interrompeu sua afeição por Euxêno, mas com permissão de seu pai, em uma

1 Siriano ao falar de Hermógenes de Tarso descreve esse mesmo rio Cydno, que corta a cidade, e diz que um Aristides vivia ali, possivelmente Élio Aristides. Ver estudo e tradução de Siriano feito por Sallum (2012, p. 69-71) e Petsalis-Diomidis (2010). 
região afastada da cidade, com um jardim delicado, perto de uma fonte, Apolônio disse ao pai: "tu vives a tua própria maneira, enquanto eu viverei como um pitagórico".

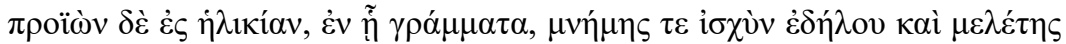

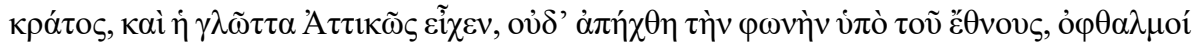

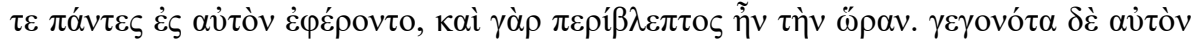

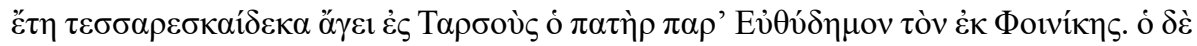

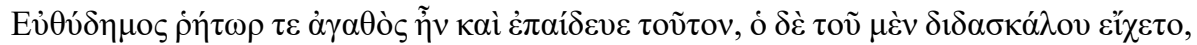
$\tau$

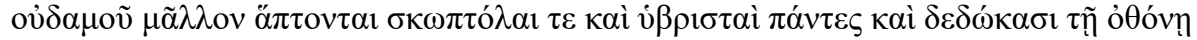

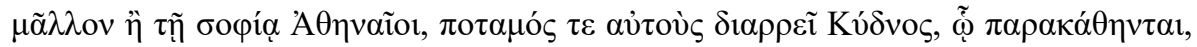

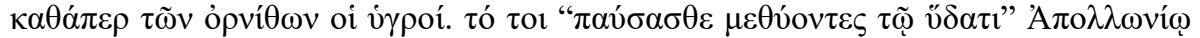

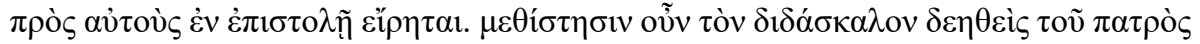

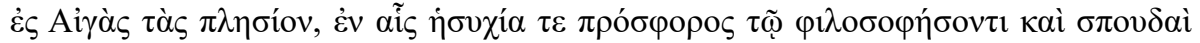

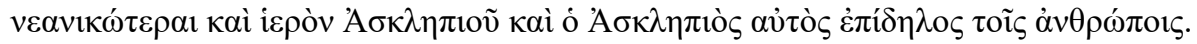

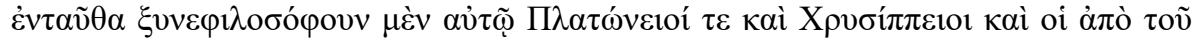

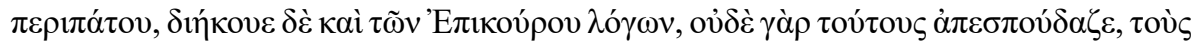

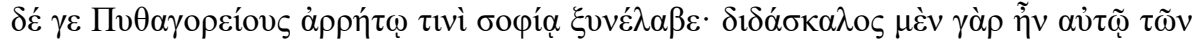

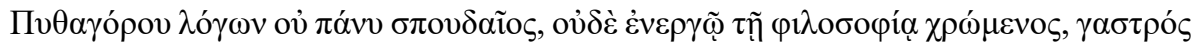

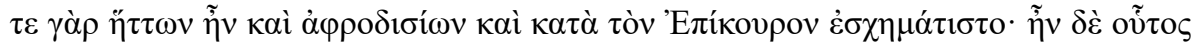

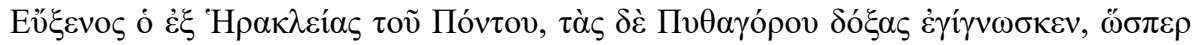

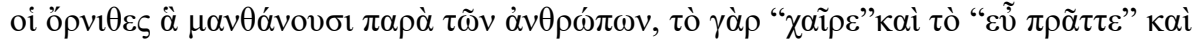

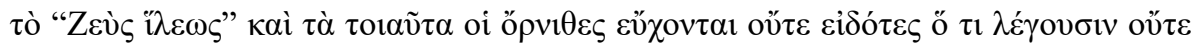

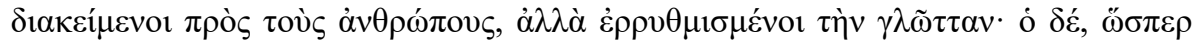

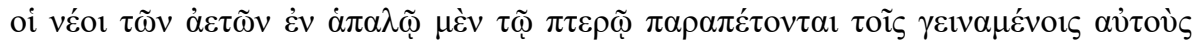

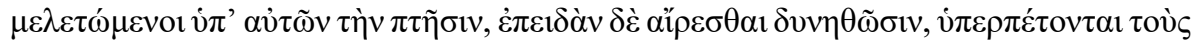

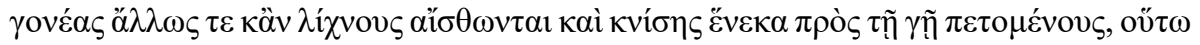

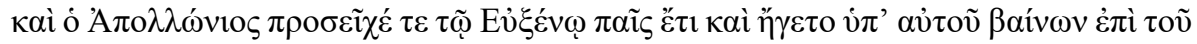

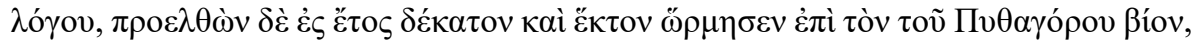

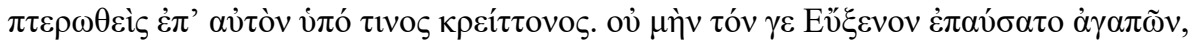

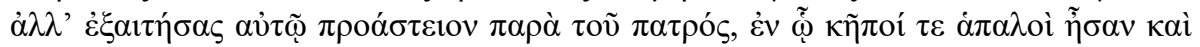

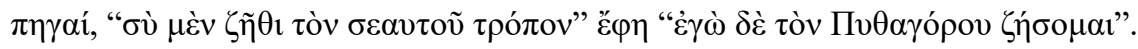

\section{Introdução}

Partindo do trecho acima, mostraremos como Filóstrato revela três aspectos importantes aos que eventualmente pretendam realizar

2 Nossa tradução. Texto grego da edição de Conybeare (1912, p.14-19). Consultamos tradução espanhola de Alberto Bernabé (1992, p. 69-71). Para uma história das edições dessa obra de Filóstrato ver Boter (2009, p.22-56). 
uma leitura mais abrangente da obra, considerando que Filóstrato é um dos idealizadores dessa nova maneira de escrever conhecida como segunda sofistica. O trecho exemplifica o quanto a segunda sofística estava empenhada no resgate e mimese das características filosóficas e literárias da época clássica, levando em conta todas as dificuldades de tal transposição, assim como revela a presença das escolas filosóficas em contraste, ou em disputa, em algumas cidades do Império Romano.

Ainda que o cenário pintado por Filóstrato não seja o mais comum quando confrontado com outros documentos da época, há nele uma nostalgia que se traduz de duas maneiras diferentes, tanto na mimese de algo que se pretendia realizar, um aticismo ou uma forma mais próxima possível do ático clássico, habilidade atribuída ao biografado, o que veremos ser inverossímil para Apolônio, bem como uma retomada de tópicos (lugares comuns) e imagens da filosofia clássica, notadamente de Platão. Curiosamente, as imagens platônicas são retomadas para explicitar a autonomia intelectual de um jovem recém "convertido" ao pitagorismo.

O nexo que reúne essas três características no trecho estudado está em observar o modo pelo qual se dá o resgate da filosofia e da expressão clássica, empreitada singular da segunda sofística, além de explicitar em alguma medida o embate entre algumas das mais importantes escolas filosóficas estabelecidas na época de Filóstrato e em período contíguo.

$\mathrm{O}$ aticismo que Filóstrato atribui a Apolônio pode ser compreendido como um elemento anacrônico, não pela mimese que ele próprio realiza, mas pela atribuição de tal característica ao biografado, completamente deslocada no tempo. O retrato das escolas vigentes e com as quais Apolônio tivera contato, por outro lado, não tem qualquer marca distintiva que as localize temporalmente com precisão, seja na época de Apolônio, seja na época de Filóstrato.

Quanto ao resgate das tópicas do Fedro de Platão, além dessas características já mencionadas, são importantes por exemplificarem como imagens platônicas são rearranjadas na explicação do processo pedagógico de Apolônio. A metáfora do progresso da autonomia intelectual servirá para indicar um tipo de escolha de vida pitagórica, apontando para uma tradicional, mas não muito bem resolvida, interseção histórica entre essas 
filosofias. Nesse ponto, constatamos uma predileção especial desses autores pelas imagens e temas provenientes da Odisseia de Homero e do Fedro de Platão, conforme explicado por Anderson (1993, p.75-76).

Todas essas características, recolhidas e explicadas nessa comunicação, pretendem mostrar como ocorre o resgate nostálgico das cores clássicas como preceito dessa literatura, ao mesmo tempo em que previne acerca da historicidade ou da falta de historicidade de algumas informações contidas na obra, agregando, portanto, algumas ferramentas de leitura para a obra. ${ }^{3}$

\section{Aticismo anacrônico e segunda sofística}

$\mathrm{O}$ trecho de Filóstrato (V.A. I, VII) é exemplar de como o autor insere elementos de seu tempo e de sua formação intelectual no personagem que está sendo biografado, no caso, como atribui ao jovem Apolônio de Tiana (15-100 d.C.) características que historicamente só poderiam fazer sentido mais de 150 anos depois, época em que a biografia foi efetivamente escrita. Embora pareça óbvia, tal constatação se faz necessária, pois é comum observar confusão, especialmente quando se desconsidera elementos constitutivos da segunda sofística, como a mimese deliberada do grego ático e a recorrência de feitos extraordinários, nesse caso de Apolônio, para validar elementos da narrativa como se fossem históricos e, portanto, verdadeiros.

Nosso primeiro apontamento ao trecho trata dessa suposta característica de Apolônio, que ainda criança mostrava espantosa habilidade mnemônica e domínio da "língua ática" (he glôtta Attikôs eikhen). Nada poderia ser mais inverossímil e, ao mesmo tempo, dentro da prescritiva da segunda sofística, simplesmente pelo fato dessa qualidade valer, sobretudo, para Filóstrato e seus sucessores, ou seja, falar bem ou escrever bem em ático foi uma virtude técnica estabelecida nesse período, não podendo ser um valor retroativo à época de Apolônio, tal como explicitado por Anderson (1993, p.85-100) e Webb (2009, p.15-17). Embora seja o aticismo uma espécie de proposta austera, segundo a qual apenas modelos áticos deveriam prevalecer,

${ }^{3}$ Ver Gyselinck \& Demoen (2009, p.95-108) acerca da ficção e meta-ficção em Filóstrato. 
ele também se mostrou como uma prescritiva ideal, que não necessariamente se verificava plenamente na prática, como elucidaram Brener \& Martins (2017, p.17), já que esses mesmos escritores carregavam outros tantos elementos culturais em sua formação, naturalmente de acordo com os diversos lugares de onde provinham.

Esse pequeno exemplo mostra que a historicidade do relato perde força frente às prescritivas inseridas no discurso do autor, não desmerecendo em absoluto o relato magistral de Filóstrato, mas, ao contrário, realocando suas ferramentas em sua própria perspectiva, para que se possa discernir melhor o que realmente pode ser considerado ligado a Apolônio, no sentido histórico, e o que apenas responde às exigências de suas convenções retóricas. Esse discernimento calibra excessos interpretativos daqueles que pretendem extrair de Filóstrato uma verdade histórica acerca de um Apolônio parcialmente ficcional. É inverossímil, portanto, quanto ao domínio do ático, que Apolônio tenha se destacado por essa qualidade na infância, uma vez que esses valores, como dissemos, estão localizados historicamente em meados do segundo século da era cristã, não antes disso.

Para além desse anacronismo supracitado, é interessante destacar que o próprio conceito de aticismo, como um modelo a ser mimetizado, já poderia ser entendido como algo deslocado e um preceito difícil de ser seguido. Tanto foi assim que conhecemos alguns esforços lexicográficos e gramaticais que procuravam fornecer aparato para que essa mimese fosse bem sucedida, tanto no seu aspecto fonético quanto em aspectos sintáticos e performáticos (Anderson, 1993, p.86-93). Resumidamente, em Roma os rétores procuravam atingir uma excelência nesse modelo clássico, o que dependia muito do empenho e do artífice. O mais interessante é que o auditório, ou pelo menos parte dele, partilhava de tais valores, que eram um tanto quanto distantes no tempo, mas que modelavam as performances desses rétores.

É nesse contexto propenso ao esmero das formalidades retóricas que o debate filosófico está inserido, não havendo uma forma filosófica isolada ou que se distanciasse efetivamente da retórica (Anderson, 1993, p.133). Nesse sentido, parece que a escola de Isócrates teve um impacto considerável na concepção de formação retórica nesse período, ainda que, 
de alguma maneira, alguns importantes elementos e temas filosóficos clássicos tenham permanecido vivos nesse amalgama retórico em suas leituras helenísticas.

$\mathrm{O}$ resultado de tal mescla entre retórica e filosofia aparece não apenas em Filóstrato, mas em inúmeros escritores e rétores, que, para além das preocupações formais, carregam traços da filosofia em seus modelos e em seus objetivos práticos. Esses profissionais do saber transitavam entre as principais cidades cujas elites podiam pagar pelos seus ensinamentos e assim instruírem seus filhos. Ainda que na maioria das vezes se tratasse apenas de um treinamento para o sucesso político, havia nessa transmissão modelos e valores derivados da filosofia, na medida em que também se demandavam tais saberes nesse pacote de ensinamentos. A retórica passa a ser um grande depósito das tradições literárias e filosóficas, para além dos exercícios de memória, de invenção, dos elogios, dos vitupérios e das formalidades técnicas do discurso em sua eficácia.

A segunda sofística evidentemente retoma e a reelabora inúmeros elementos da retórica clássica em contexto literário, filosófico e político distinto. A própria écfrase, recurso característico da obra de Filóstrato, é uma maneira de pôr algo diante dos olhos com clareza, ou seja, fazer com que a palavra, seja recitada, seja escrita, tenha tal excelência em sua capacidade comunicativa. Esse procedimento e cuidado enfatizam não apenas da narrativa (diēgēsis), mas especialmente a periēgēsis, ou seja, a trajetória discursiva circular em torno do que se diz, seja acerca das pessoas, de eventos, lugares, pinturas ou estátuas (Webb, 2009, p.53-58). ${ }^{4}$

A cena de Filóstrato mostra com clareza o processo de educação de Apolônio, as cidades em que viveu quando adolescente e o "florescer das suas asas" para a filosofia pitagórica. Filóstrato (170-250 d.C.) pinta tudo isso de modo vívido, resgatando as escolas filosóficas supostamente disponíveis e valendo-se da tópica do brotar das asas, recolhida em Platão, como metáfora sublime de sua precoce maturidade filosófica.

Observemos agora como se dá tal contraste entre as filosofias mencionadas por Filóstrato e um pouco daquele contexto, o qual talvez

4 Ver a tradução parcial dos Eikones de Filóstrato (Campos, 2017, p.5-17). 
nos revele as tendências filosóficas de um modo menos definido do que poderíamos supor, caso apenas considerássemos Filóstrato.

\section{Escolas filosóficas em contraste}

É digno de nota que a cidade de Tarso apareça como importante centro de estudos. O pai de Apolônio teria enviado primeiramente o filho à cidade de Tarso para estudar com o fenício Eutidêmo, o qual Filóstrato descreve como um "bom rétor" (Euthydêmos rhétôr te agathòs ên). $\mathrm{O}$ termo rétor, nesse caso, refere não apenas aspectos do ensino e da aprendizagem discursivas, mas também abrange o que se convencionou chamar posteriormente também filosofia, como fica claro no trecho. $\mathrm{O}$ problema desse período inicial de estudos em Tarso, como Filóstrato mostra, não estava especificamente em Eutidêmo, mas na cidade de Tarso, descrita como um lugar inapropriado para o desenvolvimento intelectual do jovem. A cidade é descrita como atípica, extravagante, literalmente átopon, sem lugar, adjetivo comumente encontrado nas descrições do caráter do próprio Sócrates em Platão, notadamente no Fedro. ${ }^{5}$

Tarso era inapropriada para a filosofia (emphilosophêsai) porque a maioria ali estava dedicada aos excessos (húbristai pántes), preocupados mais com as aparências do que com a sabedoria. A comparação com Atenas novamente ocorre, mostrando o parâmetro ideal desse período, dentro dos limites evidentes dessa execução. Nesse ponto, a imagem das aves aparece como um primeiro esboço do que será desenvolvido em seguida, referindo o rio Cydnos como palco de algo que Apolônio censurava, o deleite das pessoas às suas margens ou, como dissera em uma carta, a embriaguez nas águas do rio Cydnos. A imagem deprecia o deleite dos jovens em Tarso, os quais tornavam a cidade inadequada para os estudos da filosofia. É curioso que o valor socrático, decalcado aqui na filosofia helenística tardia, segundo o qual a imperturbabilidade deveria ser buscada, tornava-se impossível em Tarso para Apolônio, menos porque não fosse capaz de manter-se imperturbável, mas porque estava ainda em processo de formação, o que justifica a subsequente mudança de professor e de cidade,

5 Ver Pl. Phdr. átopos 229c5; atopôtatós 230c6. 
ambas gerenciadas ainda pelo pai. Apolônio vai para Egas, cidade próxima em que havia a tranquilidade necessária para que ele e muitos outros jovens se dedicassem à filosofia (philosophêsonti).

A breve menção às escolas filosóficas mostra uma sutil oposição entre o Epicurismo e outras escolas mencionadas, quais sejam, platonismo, estoicismo (chamados de crisipianos), aristotélicos e pitagóricos. Filóstrato desenha um epicurismo estereotipado com excessos alimentares e sexuais, o que jamais se encontra na filosofia de Epicuro propriamente dita, apenas nos ataques dos seus opositores históricos, configurados em caricaturas acerca da escola e dos seus seguidores. A oposição entre epicurismo e pitagorismo também é construída, pois não se sustenta num confronto mais atento com as fontes doxográficas do período, embora sirva para a caracterização cômica que Filóstrato fará de Euxeno, o segundo professor de Apolônio.

Em 178 d.C. foram recriadas quatro escolas de filosofia em Atenas, de modo que estoicos, epicuristas, platônicos e aristotélicos se reorganizaram efetivamente numa retomada da cidade de Atenas como centro cultural. Alexandria, Pérgamo, Esmirna e Antioquia já haviam se tornado mais importantes que Atenas nesse período, e todas essas "novas" escolas atenienses, pela natureza do contexto, de alguma maneira, terão elementos mesclados entre si, formando uma espécie de intercessão não muito simples de observar nem de nomear em suas nuances. De acordo com a descrição de André (1994, p.54-55) e também com as epígrafes coletadas por Lattimore (1962, p.260-263), as inscrições funerárias romanas mostram que inúmeras vezes ditos epicuristas, como "a morte não existe", se adequam perfeitamente aos epitáfios dos notáveis na aceitação da morte prematura. Além disso, diz que nessa época o epicurismo mal se distingue do hedonismo, tal qual o retrato no trecho supracitado de Filóstrato. Tal perspectiva é confirmada por Luciano Samósata, que, nesse mesmo caminho, circunscreve o epicurismo junto a um suposto hedonismo atomista, visto que pelo menos duas vezes associa Epicuro a Aristipo de Cirene $^{6}$ e faz com que em Dupla acusação (Luc. Bis Acc.20-21) Epicuro

\footnotetext{
6 Ver Luciano, Uma História Verídica (Luc. Verae Historiae II, 18). Ver Brandão (2001) para apreciação detalhada acerca da obra de Luciano Samósata.
} 
seja o advogado de defesa do prazer, frente as acusações do estoicismo personalizado. Em Hermótimo, diálogo que apresenta justamente as escolas filosóficas em contraste e suas principais características, ainda que também estereotipadas ou resumidas, Luciano (Luc. Herm.32-46) também menciona as mesmas quatro escolas referidas por Filóstrato, evidenciando certa consonância entre os imaginários de ambos os autores ao referi-las do mesmo modo, embora seus retratos não apontem para o mesmo foco que há na Vida de Apolônio, que é notadamente o pitagorismo.

Luciano, em alguns momentos, aproxima Epicurismo e filosofia Cirenaica, em outros momentos faz o contrário, afastando as escolas, como diz André (1994, p.66), distanciado o epicurismo do regozijo, da truphé, dos cirenaicos. Lattimore atesta através de inscrição funerária a proximidade do termo truphé com o universo que considera epicurista, em seção dedicada justamente às epígrafes filosóficas: "brinque, regozijese, viva, pois necessariamente morrerás" (paîson, trúphêson, zêson. apothaneîn se deî) (Lattimore, 1962, p.260).

Essas mesclas são importantes, embora não muito fáceis de compreender. Frontão, por exemplo, que foi mestre de Marco Aurélio, tinha como seu livro preferido o Fedro de Platão, pois, segundo ele, o diálogo cumpria a exigência ética e, ao mesmo tempo, contemplava a arte da palavra, de modo que esse estoicismo participa de uma espécie de família platônica em muitos pontos, mas isso não impedia que Frontão discordasse da dialética de Crisipo. André (1994, p.57-61) ressalta em Frontão uma mescla especial entre estoicismo e platonismo, bem como um concomitante afastamento da dialética de Crisipo.

Cícero já havia fornecido uma espécie de sistematização e uma escala evolutiva das escolas filosóficas em contraste, discernindo, por exemplo, a academia nova da velha academia, entre outras escolas, mas tal apresentação, por ser relativamente artificial, tendia a amenizar as diferenças entre as perspectivas, sem deixar de apresentar uma importante topografia das filosofias (Cic. De finibus, V). ${ }^{7}$ Vitrúvio, diferentemente, reconhecera as doutrinas em disputa, sem recusar nenhuma delas,

\footnotetext{
7 Ver também Laks (2006, p.25) acerca do papel sistematizador de Cícero, nesse caso evidenciado no quinto livro das Tusculanas, quando trata dos pré-socráticos.
} 
aceitando parcialmente o que lhe conviria de cada uma no campo da aplicação técnica. Talvez por isso Vitrúvio tenha sido entendido como um eclético, já que usava o empirismo epicurista, a cosmologia estoica, o enciclopedismo de Possidônio e elementos do pitagorismo. ${ }^{8}$ Em muitos desses casos, a nomenclatura do ecletismo, embora inevitável, acolhe algo impreciso, uma vez que pode reunir as mais diversas e inusitadas combinações, as quais confrontadas entre si não se parecem em nada, sendo apenas unificadas por esse "ecletismo".

A filosofia entre o fim da República Romana, em sua transição para o período Imperial, especificamente no tempo de Augusto, passa por notáveis modificações de forma e conteúdo, visto que gradativamente aparece com mais frequência no que consideramos hoje o campo da literatura do que propriamente em discursos filosóficos, entendido aqui estritamente como gênero destacado e específico. Entretanto, a filosofia não passa por uma popularização, ao contrário, apenas modifica seu modo de transmissão em outro ambiente cultural, não menos restrito, em linguagem predominantemente literária. Embora seja relativamente comum no círculo das pessoas letradas e com acesso à educação, a filosofia passa a ser uma escolha importante, pois definia expectativas e valores, os quais se manifestavam tanto na vida como nas epígrafes funerárias dos notáveis, que se preocupavam em deixar também nessas lápides suas filiações filosóficas. É interessante compreender como não apenas a literatura filosófica, mas também a arqueologia acrescentam elementos importantes ao estudo do período. As epígrafes mostram enunciados e ditos ligados a determinadas escolas filosóficas, revelando aspecto importante da mentalidade daquele tempo, contexto em que são comuns epígrafes funerárias do tipo "Epicuri filius". ${ }^{9}$

Tomemos como exemplo o estoicismo, uma das escolas mais importantes e longevas da antiguidade, escola que ganha conformação menos rigorosa do que tinha na era republicana. Suas questões especulativas perdem terreno para os preceitos morais simplificados, os quais com certa frequência aparecerão em oposição aos preceitos epicuristas, na forma de

\footnotetext{
8 Ver Vitrúvio, De arch. VII proem.2, VIII proem.1, IX proem.2-7.

9 Ver Chevallier (1972) apud André (1994, p.4, n.13).
} 
diatribes acerca dos vícios, desejos, ilusões da matéria, avareza e luxúria. Tais abordagens foram facilitadas pelos resumos tais quais os de Ário Dídimo, no qual se poderia colher de modo sinótico elementos considerados essenciais de cada escola de modo organizado e simplificado. ${ }^{10}$ Nossa recepção é muito determinada por Ário Dídimo, especialmente por ele ter sido copiado por João Estobeu e Eusébio de Cesareia. Entretanto, Sexto de Queroneia descreve melhor o tipo de estoicismo encontrado em Sêneca, que reúne em sua filosofia a ontologia platônica, a causalidade aristotélica, por vezes apagando diferenças entre as escolas, por vezes as ressaltando. ${ }^{11}$ Como exemplo de apagamento entre as diferenças entre escolas, Sêneca, em determinado momento, menciona que uma máxima epicurista era tão universal que poderia ser aceita por todas as escolas:

'Numquam volui populo placere; nam quae ego scio non probat populus, quae probat populus ego nescio.' 'Quis hoc?' inquis, tamquam nescias cui imperem. Epicurus; sed idem hoc omnes tibi ex omni domo conclamabunt, Peripatetici, Academici, Stoici, Cynici. Quis enim placere populo potest cui placet virtus?

"Nunca desejei agradar o povo; pois o povo não aprova o que eu sei, enquanto aquilo que ignoro o povo aprova". De quem é? Perguntas, como se desconhecesses tal instrução: de Epicuro. Mas essa mesma máxima será conclamada por todos em todas as escolas, peripatéticos, acadêmicos, estoicos, cínicos. Quem realmente, ao agradar o povo, pode agradar a virtude?

(Sêneca, Cartas, 29,11, 1-5) ${ }^{12}$

Os epicuristas e pitagóricos foram também constantemente contrapostos aos estoicos nas diatribes, seja porque negavam a

\footnotetext{
${ }_{10}$ Ver Ario Didimo in Etica stoica (NATALI; ANNAS, 1999).

11 Ver Sêneca, Carta 59,7, momento em que Sexto é caracterizado por Sêneca como filósofo que "escreve em língua grega, mas ao modo romano de filosofia" (Graecis verbis, Romanis moribus philosophantem) (BOELLA, 1995, p.334).

${ }_{12}$ Nossa tradução a partir da edição italiana de Boella, in Lettere a Lucilo, 29 (BOELLA, 1995, p.184-187). Ver também versão grega da máxima em questão in Epicurea (RAMELLI, 2007, p.358).
} 
providência divina ou por serem considerados materialistas, no caso dos epicuristas, enquanto os pitagóricos eram acusados em Roma por praticarem adivinhação, numerologia e astrologia. Os epicuristas tiveram adversários mais recentes nesse cenário imperial, seja por conta das questões teológicas mais relevantes, pelo estereótipo de escravos do prazer ou ainda pela atuação de muitos deles no senado, participação política que, aliás, contrariava a prescrição original de Epicuro de viver apartado (Máximas, XIV). ${ }^{13}$

$\mathrm{Na}$ Vida de Apolônio, entretanto, temos um cenário em que as escolas convivem, sem exclusão da epicurista, pois ela também era aceita por Apolônio: "Nela (na cidade de Egas) filosofavam conjuntamente platônicos, crisipianos e os do peripato, enquanto ele ouvia também os discursos de Epicuro, pois não os renegavam, embora tenha adotado o dos pitagóricos com uma inefável sabedoria". Esse retrato de Filóstrato é atípico, pois o epicurismo figura na maior parte dos relatos como uma escola duramente combatida e detratada. Outro ponto interessante do retrato de Filóstrato é que Euxêno, o professor supostamente pitagórico, vivia na verdade como um epicurista, ou como a imagem que faziam do epicurismo, mostrando a vacuidade de alguns professores com relação à doutrina que propagavam. Mesmo assim, numa atitude benevolente, Apolônio não o condenava. O descompasso entre o que se diz e a maneira de agir pode ser ampliado a todas as escolas, inclusive à pitagórica, a predileta de Apolônio, de modo que o relato se torna mais rico, visto não excluir a escola pitagórica de eventuais mazelas, numa espécie de crítica à própria escola no que concerne ao descompasso entre doutrina $\mathrm{e}$ prática por parte de alguns de seus seguidores. Nessa cena, o epicurismo estereotipado é ironicamente retratado através de um mestre supostamente pitagórico. Euxêno é como um pássaro capaz de proferir mimeticamente frases curtas de saudação ou cumprimentos, mas que, obviamente, não tem domínio algum do que diz, muito menos do que faz.

É preciso observar, entretanto, que nem sempre as escolas foram vistas com tal tolerância entre si. Especialmente no período da primeira dinastia júlio-claudiana (Augusto, Tibério, Calígula, Claudio e Nero - 27

${ }_{13}$ Ver Epicurea (RAMELLI, 2007, p.199). 
a.C. até 68 d.C.) e da dinastia flaviana (Vespasiano, Tito e Domiciano - 69 até 96 d.C.) encontramos com maior frequência exemplos de perseguição e intolerância com relação às escolas filosóficas, especialmente das inseridas e mais presentes no senado. Segundo Dion Cassius, em sua monumental História Romana (Hist Rom. 49,43), desde Augusto, em ações gerenciadas pelo seu cônsul Agripa, astrólogos e feiticeiros (astrológous te goétas) eram alvos de perseguição e expulsão em Roma.

Segundo André (1994, p.21) havia um utopismo estoico entre os senadores que se opunham a Tibério e a Claudio, o qual passa no ano de 52 a persegui-los deliberadamente, banindo do senado os chamados mathematici, os quais não se discerniam claramente dos magi (magos), neopitagóricos e astrólogos, de modo que a categorização de alguém como inimigo imperial poderia ser relativamente flutuante. Sêneca, ao falar de Sótion, um de seus mestres, explica em suas cartas como o pitagorismo era suspeito de introdução de inovações religiosas e como a eles eram atribuídos todo tipo de "heresias" (Sêneca, Epist. 108-18-22). Mesmo assim, parece que o pitagorismo estava bastante organizado, assim como o estoicismo, nas instituições políticas romanas.

André (1994, p.24) mostra que o estoicismo imperial reforçava a solidariedade da seita através das famílias, período em que aceitavam a igualdade entre gêneros e realizavam casamentos arranjados, para perpetuar as virtudes e valores através da endogamia. Entre os estoicos, amor, amizade, constância e liberdade eram virtudes esperadas e cultivadas por meio de uma complexa engenharia de arranjos familiares em vista de objetivos políticos. $\mathrm{O}$ exemplo mais eloquente de sua força e da consecutiva repressão em torno dos estoicos parece ter sido o terror que suscitou a conspiração de Pisão, contra Nero, a qual, por ter sido desvendada antecipadamente, levou à execução alguns estoicos famosos no ano de 65, entre eles Sêneca, Lucano e Petrônio.

Na época flaviana, Vespasiano, entre 93 e 94, destruirá o partido estoico através de um Édito contra filósofos e astrólogos, motivo pelo qual Helvídius Priscus pagará com a vida no ano de 93. Desse modo, observa-se que também em Roma a filosofia ou as pessoas atreladas a esse discurso e ação estavam expostas aos juízos violentos dos imperadores, 
pois a filosofia ou as filosofias estavam inseridas entre cônsules, senadores e populares, mas que, entretanto, dado o caráter de sua forma e transmissão, nem sempre estava tão acessível aos não letrados, que acompanhavam tais temas através da expressão oral nos teatros e em espaços públicos. Mesmo entre os letrados, nem sempre se podia discernir com clareza entre as escolas, talvez nem mesmo estivesse claro o pano de fundo das discussões mais elaboradas, ainda que a maioria delas tendesse para as questões morais simplificadas.

Demétrio, por exemplo, era cínico, mas ensinava dentro de parâmetros estoicos. Foi condenado ao ostracismo ao satirizar Vespasiano, que teria dito a ele depois de condená-lo, sem muita eficácia na execução da condenação: "você faz tudo para que eu te mate, mas eu não mato cão que ladra" (Dion Cassius Hist. Rom 65,13). Vespasiano, ao dar ouvidos a Muciano, expulsou todos os filósofos, exceto Mussônio Rufo, o que é paradoxal, pois a detratação de Muciano era contra as práticas exóticas estoicas, que ele considerava vazias. Mussônio foi um professor estoico renomado e teria sido poupado nessa perseguição. Segundo Dion Cassius (Hist. Rom 65,15), Heras, um filósofo cínico, não teve a mesma sorte de Demétrio, pois foi sumamente decapitado ao insultar Tito e Berenice no teatro.

Gostaria de ressaltar a importância da abordagem de André, que apresenta de modo rico como as escolas se relacionavam entre si e com o poder imperial. A única ressalva que gostaria de registrar é que algumas vezes ele usa o termo eclético, empregado comumente no período, para designar o produto das fusões entre escolas, entretanto, tais amálgamas se mostram insuficientemente descritas pela categoria ecletismo. Quando lemos os textos daquele período, é possível perceber a limitação da categoria "eclético", espécie de coringa flutuante, servindo para Demétrio, que é cético, mas ensina estoicismo, para Vitrúvio, que aceita um pouco de todos, para Horácio, que não segue ninguém, mas tem recaídas hedonistas, bem como para Apolônio, um mago pitagórico. Isso sem contar Sêneca, que tem influências pitagóricas, céticas, sendo, ao mesmo tempo, um crítico severo do dogmatismo da antiga escola estoica. Contudo, cada um desses "ecléticos" é fruto de uma mescla diversa e produzem diferentes resultados em suas inúmeras combinações específicas. 
Voltando a Filóstrato, consideramos um documento importante da formação dessas cristalizações e interpretações históricas acerca das escolas ou filosofias na era cristã, completando e confirmando algumas percepções encontradas em outros autores do período, embora existam também muitos contraexemplos, das escolas em hostilidade mútua, que acabam por torná-lo relativamente atípico, sem ser possível, entretanto, considerá-lo fruto de imaginação literária ou lugar comum da segunda sofística, como foi o caso da língua ática atribuída ao jovem Apolônio.

Euxêno de Heracleia, o segundo professor de Apolônio, revela essa imagem igualmente estereotipada das duas escolas em seu comportamento contraditório, posto que formalmente propagava a filosofia pitagórica, mas na realidade teria sido moldado em seu comportamento pelo suposto modo de vida epicurista, ou seja, é um glutão arrebatado também pelos desejos de Afrodite, ainda que, como dissemos, Epicuro nunca tenha defendido esse tipo de conduta em suas cartas, nem tampouco seus seguidores. A contradição entre a doutrina e a vida de Euxeno evidencia a dificuldade que há, nesse contexto, em seguir a austeridade da doutrina dos pitagóricos, sempre enaltecida por Filóstrato como o melhor caminho educacional e filosófico, visto que é a escolha de seu nobre biografado.

\section{Uma tópica platônica em Filóstrato}

Anderson mostra como tanto a Odisseia de Homero e como o Fedro de Platão foram textos frequentemente revisitados e reelaborados pelos escritores da segunda sofística, no caso da Odisseia pelo fato do próprio Odisseu, com sua versatilidade de viajante, sua eloquência e persuasão, ser um grande modelo que ressoava o próprio papel e a atividade do sofista em Roma (Anderson, 1993, p.75). Quanto ao Fedro, segundo Anderson, teríamos em sua abertura um modelo do locus amoenus, uma espécie de passaporte para o diálogo filosófico junto ao Ilisso, local em que os personagens junto ao plátano, acompanhados pelo canto das cigarras, estão abrigados pela écfrase (id. p.77). Isso sem contar na densa discussão acerca da retórica filosófica, local 
em que uma pequena história da retórica é contada antes de vinculá-la à dialética filosófica.

Sócrates propõe a Fedro um desvio às margens do Ilisso até chegarem ao plátano, símbolo da medicina, lugar em que encontrarão inclinação perfeita para lerem o texto que foi presenteado a Fedro, a peroração de Lísias:

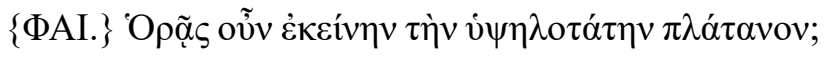
$\{\Sigma \Omega$.$\} Tí \mu \eta \dot{v}$;

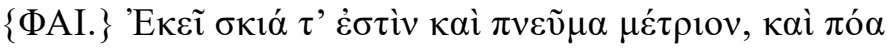

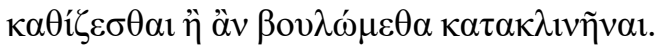

F: Vês aquele elevadíssimo plátano?

S: O que há nele?

F: Uma sombra, uma brisa moderada (pneûma métrion), uma relva para nos sentarmos e reclinarmos se quisermos (boulốmetha kataklinênai).

(Phdr. 229a3-b2) ${ }^{14}$

E ainda um pouco à frente:

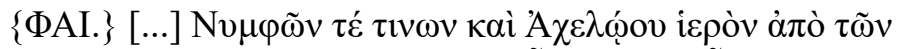

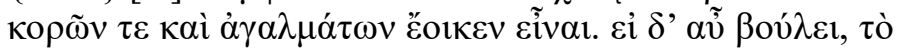

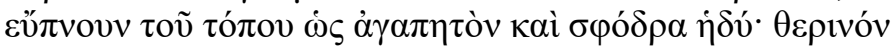

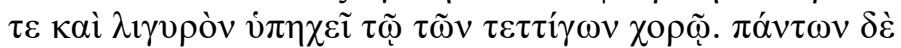

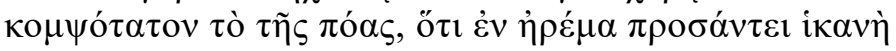

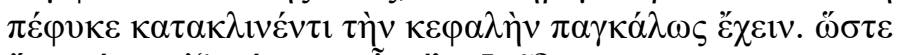

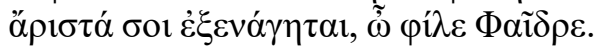

F: [...] Parece ser um templo para alguma Ninfa e para Aqueloo, a julgar pelas estátuas votivas de argila e imagens de mármore (korôn te kaì agalmátōn). Se desejas algo mais, há ainda uma doce e muito agradável brisa (eúpnoun) do lugar, estival e melodiosa, que ecoa o coro das cigarras (tettígōn khorôi). A relva é certamente o maior dos requintes (kompsótaton), porque a escarpa suave naturalmente solícita que reclinemos (kataklinenti) nossas cabeças de modo

${ }^{14}$ Nossa tradução (Campos, 2018, p.50). Texto grego tal qual Burnet (1953). Consultei também a edição de Yunis (2011, p.36). 
maravilhoso. Assim, ó querido Fedro, és o melhor dos guias para estrangeiros (exenágētai).

(Phdr. 230b7-c5) ${ }^{15}$

Além da écfrase, que não deixa dúvida quanto à importância da digressão imagética para o desenvolvimento das questões filosóficas do diálogo, a imagem da biga alada, na palinódia, também conhecida como segundo discurso de Sócrates (Phdr. 243e7-247b6), será de suma importância, justamente por descrever a natureza da alma divina e humana com recursos imagéticos similares. Acerca das imagens do florescer das asas da alma, destacamos primeiramente um dos tipos de loucura erótica descritas na palinódia, a do desejo hímeros, o mais lícito dos impulsos amorosos, onde há o preenchimento e a completude de Eros, o transbordar, o fluxo e o refluxo desse hímeros. Como esse desejo hímeros é divino, próprio dos deuses, ele seria apenas experimentado por poucos humanos, aqueles que conjugassem amor e loucura de modo divino:

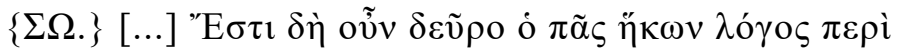

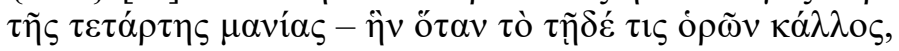

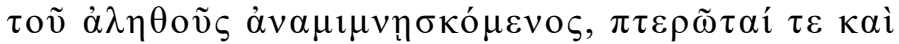

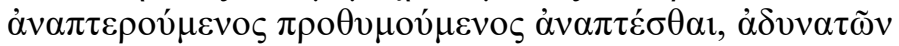

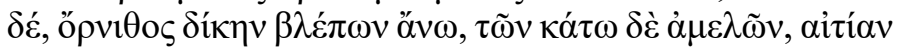

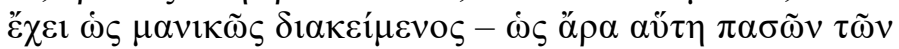

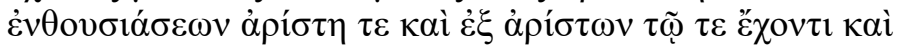

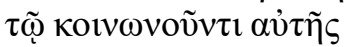

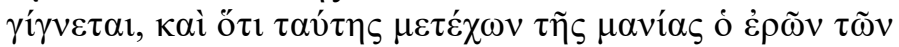

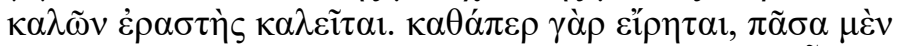

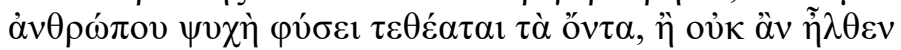

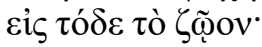

Até aqui temos o discurso todo a respeito da quarta loucura, quando [a alma] vê alguma dessas belezas, rememorando o verdadeiro (alêthoûs anamimneiskómenos) e tem as asas crescidas, momento em que a alma está alada e cheia de disposição, entretanto, quando não pode voar, ela parece um pássaro que vê o que há acima dele, mas descuida do que está embaixo, por isso é vista como uma alma louca

${ }^{15}$ Nossa tradução (Campos, 2018, p.52). Texto grego tal qual Burnet (1953). Consultei também a edição de Yunis (2011, p.37). Bowie (2009, p.72) indica nessa mesma obra de Filóstrato (Philostr. VA VII, 11) uma alusão às cigarras desse trecho do Fedro. 
(manikôs). [249e] Essa é a melhor das coisas entusiásticas (enthousiáseôn) e provém das melhores, quem dela vier a ser possuidor ou dela participar é chamado de amante do belo (kalôn erastès), porque aquele que ama é partícipe (metéchôn) da loucura (manías). De acordo com o que foi dito, é da natureza de toda alma humana ter contemplado os seres (tetheáthai tà ónta), ou não chegariam a essa vida. (Phdr. 249d4-250a1) ${ }^{16}$

No caso acima observamos o êxito da alma alada tomada pelo impulso erótico, bem como o seu eventual fracasso, quando a alma não tem a força suficiente para manter-se nessa máxima loucura e voo divinos. Essa é a melhor condição que a alma pode atingir, uma vez que segue o rastro divino, além da imagem mesma se alicerçar no voo da alma, que depende inevitavelmente da força das asas. Não menos importante é o fato de todas as almas, uma vez encarnadas, terem passado por esse nobre caminho, visto ser esta a condição sem a qual não poderia haver encarnação.

Por outro lado, há também outro tipo de loucura erótica presente na palinódia, lugar em que as imagens aladas também estão presentes, só que agora descrevendo a philía erótica, um estágio anterior ao hímeros, pois não há o voo, apenas efeitos preliminares: o preenchimento das asas, a oftalmia e um espelhamento entre amante e amado, literalmente, uma ligação regida pelos olhos que provoca uma reflexão de si no outro. Além do desequilíbrio emocional desse estado, tal sopro tem uma fisiologia específica, descrito como um fluxo da beleza, mobilizador da philía erótica:

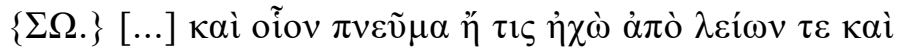

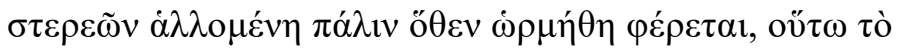

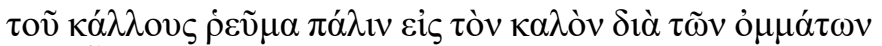

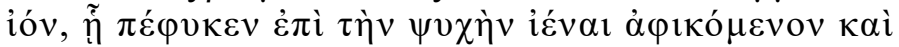

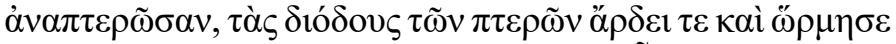

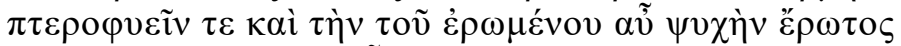

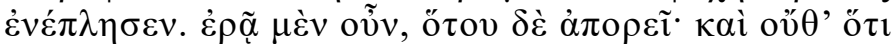

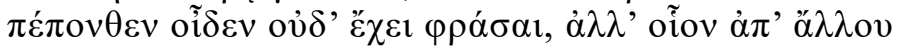

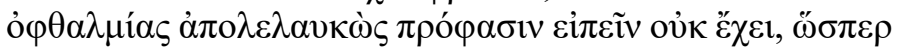

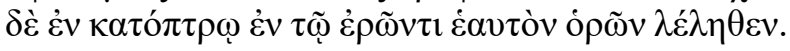

${ }^{16}$ Nossa tradução (Campos, 2018, p.87). Texto grego tal qual Burnet (1953). Consultei também a edição de Yunis, que desconsidera o primeiro travessão do trecho e coloca o relativo ìv entre vírgulas (Yunis, 2011, p.54; 147). 
S: [...] Tal qual um sopro (pnêuma) ou algum eco (êkhô) que numa superfície lisa ou sólida é levado novamente (pálin) ao ponto de partida, assim o fluxo da beleza é novamente (pálin) direcionado ao belo, através dos olhos (ommátôn), por onde a alma é acessada e tem as asas acrescidas (anapterôsan). [255d]

Então, as vias das asas são irrigadas (pterôn árdei), iniciando o seu brotar (pterophyeîn), enquanto o amor preenche (érôtos enéplêsen) a alma do amado (erôménou). Ele ama, mas não sabe o quê. Não sabe o que sofre e não tem como expressar isso. Tal qual uma oftalmia (ophthalmías) adquirida de outrem, ele não tem como expressar a causa, uma vez que lhe escapa (lélêthen) que vê a si mesmo no seu amante, como se fosse em um espelho (katóptrôi).

$\left(\right.$ Phdr. 255c2-255d5) ${ }^{17}$

Munidos agora de algumas ferramentas platônicas, passemos ao nosso terceiro e último aspecto a ser ressaltado no trecho de Filóstrato, lugar em que há uma curta écfrase de Filóstrato inspirada na écfrase de Platão. A imagem é a dos filhotes de águias, que quando jovens voam próximos dos seus ninhos, para que seus pais os instruam nos seus primeiros voos. Depois, com o crescimento de suas asas e a brevíssima experiência, esses filhotes passam a ser capazes de voos mais distantes. Essa é a metáfora da relação de Apolônio com o seu mestre Euxêno, uma vez que aos dezesseis anos, sem deixar de admirar o mestre "pseudo" pitagórico, ele decidirá viver uma vida pitagórica "de verdade", não como a de Euxêno. Nesse momento, mais uma vez, seu pai aparece, mas a partir de agora não mais decidirá a respeito dos rumos educacionais do filho, pois Apolônio será bem claro em sua decisão. Esse será um momento protréptico de Apolônio, uma decisão acerca da vida pitagórica que levaria daí em diante, mas a imagem que usa é bastante conhecida, a do crescer das asas: "uma força fez com que suas asas crescessem" (pterôtheìs ep' autòn hupo tinos kreittonos).

Essa tópica usada por Filóstrato retoma as imagens ligadas ao crescer das asas e da ascensão ao lugar supracelestial no Fedro. Sócrates diz que "só cria asas (pteroûtai) o pensamento (diánoia) do filósofo" (Phdr. 249c4-5), também que "rememorando o verdadeiro (alêthoûs

${ }_{17}$ Nossa tradução (Campos, 2018, p.97). Texto grego tal qual Burnet (1953). Consultei também a edição de Yunis (2011, p.59). 
anamimneiskómenos) tem as asas crescidas (pterôtai), momento em que a alma está alada (anaptésthai)" (Phdr. 249d5-7). Descreve tal processo também quando diz que a alma "no começo do crescer das asas (pterophyeîn), ferve e irrita-se com as cócegas provocadas pelo brotar das asas (phýousa tà pterá)" (Phdr. 251c4-5), e ainda "através dos olhos (ommátôn), por onde a alma é acessada e tem as asas acrescidas (anapterôsan)"'(Phdr. 255c5-6). ${ }^{18}$

Nesse espectro de imagens do florescer das asas, ou seja, das capacidades intelectuais e mnemônicas das almas, Sócrates afirma que "as vias das asas são irrigadas (pterôn árdei), iniciando o seu brotar (pterophyeîn), enquanto o amor preenche (érôtos enéplêsen) a alma do amado (erôménou)" (Phdr. 255c6-d3), ressaltando ainda que algumas almas "ganham asas e leveza (hypópteroi kaì elaphroi), pois venceram um dos três combates verdadeiramente olímpicos, o qual é o maior bem (agathòn)" (Phdr. 256b3-6). ${ }^{19}$

Toda a imagem da alma que alcança o lugar supracelestial no Fedro é retomada de modo bastante sutil, como quase tudo em Filóstrato, para elucidar o desprendimento de Apolônio de seu segundo mestre, Euxêno, e de alguma maneira também de seu pai, já que no final do parágrafo Apolônio foi categórico ao dizer ao pai que viveria uma vida pitagórica dali em diante, independentemente do que ele considerasse adequado, marcando também um momento de independência completa do desenvolvimento intelectual de Apolônio. Nesse momento encontramos o fim de uma vida tutelada e o começo de uma nova vida, uma espécie de despertar intelectual do jovem Apolônio brilhantemente descrito por Filóstrato.

\section{Apontamentos finais}

Resumidamente, o trecho de Filóstrato reverbera alguns temas importantes e que podem ser úteis para o leitor da obra, pois o que acontece nesse microcosmo potencialmente ocorre em outros pontos. Embora aqui nenhuma outra conexão interna à obra tenha sido estabelecida, pois não era esse o nosso objetivo, expusemos de modo cautelar alguns poucos e úteis elementos de leitura.

18 Ver nossa tradução (Campos, 2018, p.86-98).

19 Ver nossa tradução (Campos, 2018, p.97-99). 
Destacamos os potenciais anacronismos, o aticismo de Apolônio, que na verdade é apenas de Filóstrato, o retrato das escolas filosóficas, amparado em outros elementos importantes, bem como a ligação com Platão, relação não indicada nem pelos tradutores consultados, nem por Bowie (2009), que estuda justamente citações e alusões dessa obra de Filóstrato a textos mais antigos.

Procuramos mostrar esse imaginário constitutivo da segunda sofística através de um lugar comum no oceano de imagens e prescritivas de Filóstrato. Em seguida, evidenciamos os estereótipos das escolas filosóficas, algo bastante interessante, com destaque para a detratação do epicurismo, como se fosse uma filosofia que tivesse em algum momento defendido a glutonaria e a desmedida nos impulsos sexuais. Embora Apolônio se mostre complacente com seu mestre, o estereótipo da filosofia epicurista foi confirmado pela descrição da conduta desregrada do mestre. $\mathrm{O}$ estereótipo distorcido do epicurismo se mostra bastante assentado nesse período, informação importante no recenseamento da doxografia acerca do epicurismo, mas também, como vimos, na observação da profusão das escolas e na mescla de seus elementos, algo que não poderia de modo algum se encerrar na categoria "ecletismo".

Em Filóstrato, contudo, o retrato do estoicismo se dá por meio da expressão "crisipianos", mostrando que Crisipo nesse tempo já estava bastante fixado como o sintetizador predominante do estoicismo, embora tivesse seus críticos no mesmo estoicismo, além da menção bastante eloquente da tópica platônica das asas da alma, que quando irrigadas suficientemente crescem a ponto de elevar seu dono ao lugar supracelestial e, consequentemente, às visões e rememorações próprias desse nobre lugar. Ao mesmo tempo platônico e pitagórico, a imagem perfaz uma luminosa metáfora do desenvolvimento educacional e intelectual do jovem Apolônio retratado por Filóstrato.

\section{Referências}

ANDERSON, G. The second sophistic: a cultural phenomenon in the Roman empire, Routledge, New York, 1993.

ANDRÉ, J. -M. Les ecoles philosophiques aux deux premiers siècles de l'Empire, In Aufstieg und niedergang der römischen welt, Band II. 36.1 (Org. von Wolfgang HAASE \& Hildegard TEMPORINI), WALTER DE GRUYTER: Berlim, 1987, p.5-77. 
ARIO DIDIMO \& DIOGENE LAERZIO. Etica stoica, a cura de Natali, C., introd. Annas, J., Laterza, Roma-Bari,1999.

BOTER, G. Towards a New Critical Edition of Philostratus'Life of Apollonius: The Affiliation of the Manuscripts. p. 21-56; In: Theios Sophistes, Essays on Flavius Philostratus' Vita Apollonii, Edited by Kristoff el Demoen and Danny Praet, Netherland: Brill, 2009.

BOWIE, E. Quotation of earlier texts.p. 57-73; In: TA E $\Sigma$ TON TYANEA AПO $\Lambda \Lambda \Omega N I O N$ In Theios Sophistes, Essays on Flavius Philostratus' Vita Apollonii, Edited by Kristoff el Demoen and Danny Praet, Netherland: Brill, 2009.

BRANDÃO, J. L. A Poética do Hipocentauro. Literatura, sociedade e discurso ficcional em Luciano de Samósata. Belo Horizonte: UFMG, 2001.

BRENER, P. Z. \& MARTINS, P. Novas luzes sobre a Segunda Sofística, Codex - Revista de Estudos Clássicos, ISSN 2176-1779, Rio de Janeiro, vol. 5, n. 2, jul.-dez., 2017, p.11-28.

BURNET, J. Platonis Opera tomus II, Oxford: Oxford Classical Texts, 1953.

CAMPOS, R. G. de. Eikones de Flávio Filóstrato, o velho. Rapsódia, [S. l.], n. 10, p. 5-17, 2017. Disponível em: https://www.revistas.usp.br/ rapsodia/article/view/127339. Acesso em: 20 jun. 2021.

CICERÓN, M. T. De los fines de los bienes y los males, Libros III-V, traducción y notas de Julio Pimentel Álvarez, Editorial UNAM, México, 2003.

DIO CASSIUS. Roman History, Volume V: Books 46-50. Translated by Earnest Cary, Herbert B. Foster. Loeb Classical Library 82. Cambridge, MA: Harvard University Press, 1917.

DIO CASSIUS. Roman History, Volume VIII: Books 61-70. Translated by Earnest Cary, Herbert B. Foster. Loeb Classical Library 176. Cambridge, MA: Harvard University Press, 1925.

EPICUREA. a cura di RAMELLI, Milano: Bompiani, 2007.

FILÓSTRATO. Vida de Apolonio de Tiana; Trad. BERNABÉ, A. P., Madrid: Editorial Gredos, 1992.

GYSELINCK, W. \& DEMOEN, K. Author and narrator: Fiction and Metafiction in Philostratus'Vita Apollonii. p. 95-127; In: KRISTOFF; D.; PRAET, D (ed.). Theios Sophistes: Essays on Flavius Philostratus' Vita Apollonii. Leida: Brill, 2009. 
LAKS, A. Introdução à "filosofia pré-socrática", São Paulo: Paulus, 2006. LATTIMORE, Richmond. Themes in Greek and Latin Epitaphs, University of Illinois Press, Urbana, 1962.

LUCIAN. A True Story. Slander. et alli. In vol. I, Translated by A. M. Harmon. Loeb Classical Library 14. Cambridge, MA: Harvard University Press, 1913.

LUCIAN. The Double Indictment or Trials by Jury. et alli in vol. III, Translated by A. M. Harmon. Loeb Classical Library 130. Cambridge, MA: Harvard University Press, 1921.

LUCIAN. Hermotimus or Concerning the Sects. et alli in vol. VI, Translated by K. Kilburn. Loeb Classical Library 430. Cambridge, MA: Harvard University Press, 1959.

PETSALIS-DIOMIDIS, A. Truly Beyond Wonders Aelius Aristides and the Cult of Asklepios, Oxford University Press Inc., New York, 2010.

PHILOSTRATUS. The Life of Apollonius of Tyana, vol.1, trad. CONYBEARE, Loeb, 1912.

PLATÃO. Fedro, trad. Campos, R. G. de. São Paulo: Hedra, 2018. SALLUM, J. L. F. Sobre sofística e filosofia no platônico Siriano Filoxeno, "o isocrático". Mestrado Faculdade de Filosofia, Letras e Ciências Humanas, Universidade de São Paulo, São Paulo, 2012. doi:10.11606/D.8.2013.tde-11062013-131224. Récupéré 201910-21, de www.teses.usp.br

SENECA. Lettere a Lucilio, (org.) BOELLA, Torino: Unione Tipografico Torinese, 1995.

VITRUVIO. De architetura, trad. Migotto, Studio Tesi, 1991.

WEBB, R. Ekphrasis, imagination and persuasion in ancient rhetorical theory and practice, England: Ashgate, 2009.

YUNIS, H. Phaedrus, edited with commentary by Yunis, Cambridge: Cambridge Press, 2011.

Recebido em: 27 de janeiro de 2021 .

Aprovado em: 26 de julho de 2021. 